\title{
Relationships between production and product traits in subpopulations of Bonsmara and Nguni cattle
}

\author{
P.E. Strydom ${ }^{1 \#}$, R.T. Naudé ${ }^{2}$, M.F.Smith ${ }^{2}$, A. Kotzée ${ }^{3}$, M.M. Scholtz ${ }^{3}$ and J.B. van Wyk ${ }^{4}$ \\ ${ }^{1}$ Animal Nutrition and Animal Products Institute, ARC, Private Bag X2, Irene 0062, South Africa; ${ }^{2}$ ARC Head Office, \\ P.O. Box 8783, Pretoria 0001, South Africa; ${ }^{3}$ Animal Improvement Institute, ARC, Private Bag X2, Irene 0062, South \\ Africa; ${ }^{4}$ Department of Animal Science, University of the Orange Free State, P.O. Box 339, Bloemfontein 9300,
} South Africa

\begin{abstract}
Ninety bull calves of five Bonsmara strains, viz. Edelheer (E), T-49 (T), Wesselsvlei (W), Roodebos (R) and Belmont Red (BR), and two Nguni sub-populations, viz. Bartlow (B) and non-Bartlow (NB), were fattened under intensive feeding conditions and serially slaughtered at four different slaughter weights. Phylogenetic relationships between the five Bonsmara strains and between the two Nguni subpopulations were determined by means of blood typing. Growth performance, carcass characteristics and meat quality characteristics were compared between the sub-populations of each breed. Genetic distances between the Bonsmara animals confirmed the existence of five genetic subpopulations with variation in genetic distances between them. The genetic distance between the two Nguni subpopulations was very small, indicating genetic similarity. Means for production and product characteristics were adjusted for mean subcutaneous fat percentage by means of analysis of covariance. T gained weight faster and more efficiently on a live and carcass weight basis than the other Bonsmara groups, while B gained carcass and muscle weight more efficiently than NB. T had proportionally more meat in the high-priced cuts of the carcass than W. Muscle of the $\mathrm{W}$ line had a higher ageing potential (measured as myofibrillar fragmentation; MFI) than T, resulting in higher tenderness scores for W. Similarly, B had higher MFI for muscle aged for one or seven days, coupled with more tender meat than NB. Pairwise correlations between growth and muscle characteristics indicated that fast growing animals tend to produce less tender meat.
\end{abstract}

\section{Introduction}

The Bonsmara is an indigenous composite breed which originated in the early 1940 s from a $5 / 8: 3 / 8$ combination of the Afrikaner (indigenous Sanga or Bos taurus africanus) and Shorthorn/Hereford (Bos taurus taurus) through an initiative of the former Department of Agriculture of South Africa (Bonsma, 1980). By 1970, the genetic structure of the breed had narrowed considerably due to over-exploitation of the Edelheer strain, which was the dominant breeding line in most Government stud herds. Consequently, it was decided to develop other subpopulations within the Government herds and certain private herds to reestablish genetic variation within the breed (Bosman, 1988). The Edelheer (E) breeding line (progenitor, the bull Edelheer) is still regarded as the main strain of the breed, since it dominated the A.I. industry of the Bonsmara prior to the introduction of the other subpopulations. The Wesselsvlei (W) strain originated from the bull Spanner, a 5/8 Afrikaner x 3/8 Red Poll bull, instead of the normal Afrikaner/Hereford/Shorthorn combination, while the Roodebos (R) strain was developed from an unrelated group of animals in a specific Government herd. T-49 (T) is not a formal strain, but was regarded as an independent strain for the purposes of this study due to the large number of animals within the E strain that were related to a certain bull, T- 49 . This bull achieved exceptional growth performance indices in the National Performance Testing Scheme (Bosman, D.J., 1996 - personal communication). The Belmont Red (BR) is an independent breed, developed in Australia from 1/2 Afrikaner, 1/4 Shorthorn and 1/4 Hereford. It was imported into South Africa and was further developed as an unrelated subpopulation within the Bonsmara breed.

Sanga cattle (Bos taurus africanus), of which the Nguni is an ecotype, may have evolved from crosses between Zebu and humpless Hamitic Longhorn and Shorthorn cattle in central and east Africa around 1600 B.C. (Payne, 1964; Schoeman, 1989). Although the Nguni has been farmed in South Africa for a considerable period of time, prejudice against indigenous cattle brought this breed close to extinction in 1949 (Stoch, 1993). Government-appointed efforts by Bonsma et al. (1951), however, led to steps that were taken to arrest breed degradation and establish a pure breed. Two breeding stations were established, viz. Bartlow Combine in KwaZulu-Natal province and Mpisi in Swaziland (Ronchietto, 1993), but only the former station 
played a major role in the initial conservation of the breed. This herd was isolated and no genetic material entered from other non-related herds. In recent years, several government herds were established to conserve distinctive Sanga subpopulations, e.g. Pedi, Venda, Shangaan in Gazankulu and Zululand (Nguni) types. A breed society was established in 1986 with 123 members (13 700 animals) active at present (Anon, 1998). Although of relatively small frame size, the Nguni is attracting international interest, mainly due to characteristics acquired through centuries of natural selection in a very adverse environment, i.e. high fertility, short intercalving period, ease of calving, low calf mortality, cow efficiency and tick resistance (Maule, 1973; Scholtz, 1988; Schoeman, 1989).

In this study the phylogenetic relationships between the five Bonsmara strains and between the two Nguni subpopulations (based on origin) were determined and production and product characteristics of these groups were compared within each breed.

\section{Materials and methods}

Forty Nguni and 90 Bonsmara weaner bulls (approximately seven months old) were selected from various herds throughout South Africa. The Bonsmara was represented by five different strains, viz. $\mathrm{E}(\mathrm{n}=$ 18), $\mathrm{T}(\mathrm{n}=18), \mathrm{R}(\mathrm{n}=18), \mathrm{W}(\mathrm{n}=18), \mathrm{BR}(\mathrm{n}=18)$. Two subpopulations were distinguished within the Nguni breed on the basis of origin, viz. the Bartlow Combine type $(B ; n=20)$, represented by animals from the Bartlow herd that was isolated for almost 40 years, and a non-Bartlow group $(\mathrm{NB} ; \mathrm{n}=20)$, which is considered to be genetically less inbred than the former.

Animals of each breed were stratified into four groups according to liveweight. One group of animals was slaughtered at commencement of the trial (S0), while the other groups represented slaughter weights of $75 \%$ (S1), 90\% (S2) and 105\%(S3) of the final weight of the 112 day Standardised Growth Test of the National Beef Cattle Performance Testing Scheme (Anon, 1994) for each breed (Table 1).

Table 1 Mean slaughter weight for two breeds and mean subcutaneous fat level for different subpopulations within breeds at three slaughter endpoints

\begin{tabular}{lccc}
\hline & & Slaughter weight & \\
& ${ }^{1} \mathrm{~S} 1(75 \%)$ & $\mathrm{S} 2(90 \%)$ & $\mathrm{S} 3(105 \%)$ \\
\hline Bonsmara & 349.4 & 412.0 & 477.5 \\
Nguni & 248.6 & 302.5 & 342.0
\end{tabular}

Bonsmara:

$\begin{array}{lllr}\text { Edelheer } & 3.50 & 5.65 & 5.89 \\ \text { T-49 } & 4.89 & 4.53 & 5.83 \\ \text { Wesselsvlei } & 4.19 & 4.76 & 5.74 \\ \text { Belmont Red } & 4.19 & 4.27 & 4.91 \\ \text { Roodebos } & 4.41 & 5.70 & 5.67\end{array}$

Nguni:

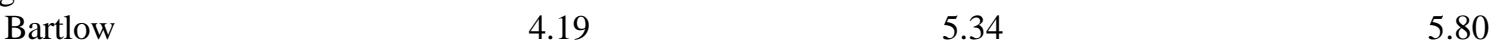

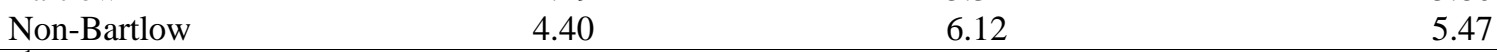

${ }^{\mathrm{I}} \mathrm{S}=$ Slaughter groups representing slaughter weights of $75 \%, 90 \%$ and $105 \%$ of the final weight of the Phase C performance test (112 day Standardised Growth Test; Anon, 1994) for each breed

The animals were kept in single pens and fed a commercial pelleted diet that is normally used in Phase $\mathrm{C}$ of the National Beef Cattle Performance Testing Scheme, with a calculated nutritional value of 10,70 MJ $\mathrm{ME} / \mathrm{kg}, 13.20 \%$ protein, $0.80 \%$ calcium, $0.47 \%$ phosphorus and $12.80 \%$ fibre (as fed basis). Due to the relatively low energy content, the diet can not be considered to be a true finishing diet. Eragrostis tef hay was supplied at $1 \mathrm{~kg}$ per day together with the pelleted diet that was fed on an ad lib. basis. Individual feed intake (as fed basis) was recorded bi-weekly and live weight was recorded weekly. These measurements were used to determine feed conversion ratio (FCR) and average daily gain (ADG). ADG and FCR for carcass and meat at each of the three slaughter points, S1, S2 and S3, were determined using the carcass weight and carcass composition of S0 as basis. The average dressing percentage and carcass composition of 
animals allocated to S0 was used to calculate the carcass weight and carcass composition of animals in the other slaughter groups at the commencement of the growth period.

Blood samples were collected from each animal at commencement of the trial. Phylogenetic relationships between the subpopulations were studied using gene frequency values obtained from electrophoretic analysis of eight structural gene loci that code for blood-soluble proteins together with 23 blood group loci. Estimates for genetic distances between populations, phenograms, cladograms, and the goodness-of-fit statistics of dendrograms were computed using the BIOSYS-1 program (Swofford \& Selander, 1981).

Animals were slaughtered on reaching the respective slaughter group target weights and dressed at a local research abattoir according to commercial practice. Carcasses were electrically stimulated (ES: 2 min. at 500 volts, 11.1 pulses per second) immediately after exsanguination to control the effect of rapid chilling on cold shortening of muscles. Carcasses were split, weighed and then chilled at $3 \pm 3^{\circ} \mathrm{C}$ before being processed on the day following slaughter. Carcass length.(the distance between the cranial side of the centre point of the first rib and the centre point of the iliopubic fusion of the pelvis), and buttock length (the distance between the centre point of the iliopubic fusion of the pelvis and the distal edge of the pelvic limb) were determined to calculate carcass compactness (carcass side weight $\div$ side length) and hindquarter compactness (hindquarter weight $\div$ buttock length). The right sides were quartered between the 9th and 10th thoracic vertebrae where the eye muscle area was measured as the length $\mathrm{x}$ width of the $M$. longissimus thoracis (LT). The two quarters of the right sides were processed into 15 wholesale cuts according to the London and Home Counties cutting techniques (Gerrard \& Mallion, 1977) and Bisschop (1946, as described by Naudé, 1974; Figure 1), which were dissected into meat (muscle + intermuscular fat), subcutaneous fat (SCF) and bone. The composition of each cut and the whole carcass side as well as the distribution of bone, meat and subcutaneous fat in the carcass side were determined from the weights of the various tissues. The meat and subcutaneous fat of the prime rib cut ( 8 to $10^{\text {th }}$ rib; Figure 1) were ground, mixed and analyzed for percentage protein, moisture, ash and fat (A.O.A.C., 1985). As the prime rib cut is highly correlated with carcass composition, the percentage yield of muscle and total fat were calculated from the chemical (fat, ash, protein, moisture) and physical composition of this cut (Naudé, 1972). The LT of the wing rib cut (11 ${ }^{\text {th }}$ to $13^{\text {th }}$ rib; Figure 1) of the right side was retained after separating bone, fat and lean to determine the degree of intra-muscular fat (marbling) in the LT muscle (A.O.A.C., 1985).

The LT and LL of both carcass sides were used for muscle biochemistry, histology and meat quality analysis. The LT of the prime rib and the whole wing rib cut (Figure 1) were removed from the left side, vacuum packed and aged for seven days at $3 \pm 3^{\circ} \mathrm{C}$. The samples were then frozen at $-20^{\circ} \mathrm{C}$ until analysed for collagen content and solubility (Bergman \& Loxley, 1963; Hill, 1966; Weber, 1973), and sensory and physical parameters. Three samples (50g) of the M. longissimus lumborum (LL; $1^{\text {st }}$ lumbar vertebrae) of the right side were retained, vacuum-packed and aged at $3 \pm 3^{\circ} \mathrm{C}$ for 1,7 and 14 days respectively for determination of myofibrillar fragmentation index (MFI) according to the method of Culler et al. (1978) as adapted by Heinze \& Bruggemann (1994).

Wing rib cuts were thawed at $7^{\circ} \mathrm{C}$ and oven roasted (oven temperature $=160^{\circ} \mathrm{C}$ ) to an internal temperature of $70^{\circ} \mathrm{C}$, whereupon they were bisected. The one half was used for sensory analysis and was sampled directly after cooking, while the other half was used for shear force measurement. A ten-member trained descriptive panel was used to describe and quantify differences between muscle samples $(M$. longissimus thoracis, wing rib) under controlled conditions. Panellists were selected and trained in accordance with AMSA Guidelines for Cooking and Sensory Evaluation of Meat (AMSA, 1978) and the procedures of Cross et al. (1978). Aroma intensity, juiciness, overall tenderness, residual amount of connective tissue and overall flavour intensity were evaluated on an 8-point scale. A score of 8 described the sample as extremely intense in aroma and flavour, extremely juicy, extremely tender with no connective tissue residue, while a score of 1 described it as extremely bland in aroma and flavour intensity, extremely dry, extremely tough with extremely abundant connective tissue residue.

The samples designated for shear force measurement were chilled and stored at $4^{\circ} \mathrm{C}$ overnight, whereupon they were allowed to reach room temperature (centrally controlled at $22^{\circ} \mathrm{C}$ ) before being cored. Cylindrical samples with a core diameter of $25 \mathrm{~mm}$ were removed parallel to the grain of the meat and sheared perpendicular to the fibre direction using a Warner-Bratzler shear device mounted on an Universal Instron apparatus (Instron Corporation, 1990). The reported value in Newton represented the average peak force measurement. 
A $100 \mathrm{~g}$ sample of the LL ( $3^{\text {rd }}$ lumbar vertebrae, left side) was removed directly after exsanguination and before ES of the carcass and frozen in liquid nitrogen. The nitro-blue tetrazolium technique of Malaty \& Bourne (1953) was used for histochemical detection of succinate dehydrogenase in mitochondria. Fibres were classified by means of video image analysis (VIA: Kontron Germany) into red, intermediate and white according to the intensity of the staining reaction. Fibre cross-sectional areas were also determined by VIA. A $20 \mathrm{~g}$ sample of the LT of the left side, removed at $24 \mathrm{~h}$ after slaughter, was prepared according to the method of Hegarty \& Naudé (1970), and was used to determine sarcomere length by means of VIA (Kontron Germany).

$$
\begin{aligned}
& 1 \text { - Neck } \\
& 2 \text { - Foreshin } \\
& 3 \text { - Shoulder } \\
& 4 \text { - Chuck } \\
& 5 \text { - Brisket } \\
& 6 \text { - Prime rib } \\
& 7 \text { - Wing rib } \\
& \text { 8- Loin } \\
& \text { 9- Thin flank } \\
& 10 \text { - Rump } \\
& 11 \text { - Fillet } \\
& 12 \text { - Thick flank } \\
& 13 \text { - Silverside } \\
& 14 \text { - Topside } \\
& 15 \text { - Hindshin }
\end{aligned}
$$

Forequrter cuts: $1,3,4$

High-priced cuts: $6,7,8,10,11,12,13,14$

Ventral cuts: 5,9

Shin cuts: 2,15

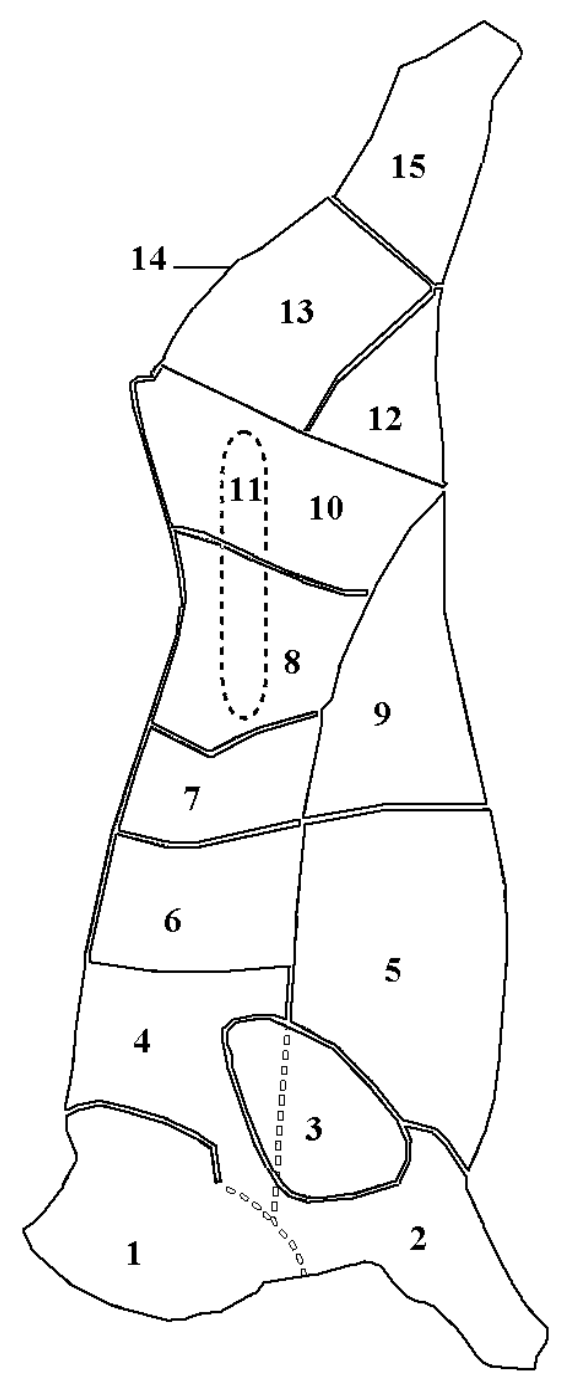

Figure 1 Diagram of carcass cuts according to the London and Home Counties cutting techniques (Gerrard \& Mallion, 1977) and Bisschop (1946, described by Naudé, 1974). 
Sources of variation were investigated by analysis of variance (ANOVA) or analysis of covariance (ANCOVA). Only the effect of subpopulation was addressed in the discussion. In an attempt to quantify carcass characteristics of the various subpopulations within the two breeds in a market-related way, subcutaneous fat percentage (SCF) was used as covariate in an ANCOVA, thereby adjusting means to mean overall SCF percentages of $5.2 \%$ and $4.8 \%$ for the Bonsmara and Nguni groups, respectively. SCF is the only norm currently used to classify beef carcasses in terms of lean yield within age classes in the South African classification system (Government Gazette No.5092, 1993). Fatness levels of 5.2\% and 4.8\% SCF represent the fat-code range between 2 and 3, which applies to $75 \%$ of all carcasses currently sold through auction markets in South Africa. ANCOVAs were performed using the general linear model facility of the Genstat 5 statistical program (Genstat 5 Committee, 1993) to establish more reliable estimates of treatment means adjusted for mean SCF percentage, since the normal ANCOVA procedure implies parallel lines (equal slopes) of all treatment groups (breeding lines/subpopulations) for the regression between the covariate (SCF) and a variate. Means were adjusted for mean starting weight within each breed to reduce the effect of weight at commencement of the trial. The covariant was removed from the model if not significant $(\mathrm{P}>$ 0.05) and the usual ANOVA was carried out to quantify variation between subpopulations. Means separation was achieved by application of the Bonferroni Multiple Comparison Method at the 5\% level. Pairwise correlations were determined within breeds to describe the linear relationships between any two characteristics. Significance $(\mathrm{P}<0.05)$ of correlations was determined relative to zero for $n$ - 2 degrees of freedom, where $n$ is the number of values for each pair of traits.

\section{Results and discussion}

The phylogenetic study revealed heterozygosity levels varying between $31 \%$ and $43 \%$ for the Bonsmara. The lowest level was observed in T, which is in accordance with the development history of this strain which shows that it is the most inbred. The highest heterozygosity levels were observed in E and R, which represent the largest part of the Bonsmara population. Two clusters were observed (Figure 2): one was represented by $\mathrm{W}$ and another by the rest of the population, except BR, which separated from the hypothetical trunk at an early stage. Within the second cluster, E and T showed a higher relationship, differentiating from R. E and $\mathrm{R}$ were more related than $\mathrm{E}$ and $\mathrm{W}$. The cladogram was topologically similar to the phenogram (dendrogram), which corroborates the stability of the classification. The rate of inbreeding relative to the other strains in the breed, $\mathrm{F}_{\text {is }}$, confirmed that $\mathrm{T}$ had the highest level of homozygosity $\left(\mathrm{F}_{\text {is }}=\right.$ $25.0 \%$ ), followed by BR, $\mathrm{W}, \mathrm{E}$ and $\mathrm{R}$ with $\mathrm{F}_{\text {is }}$ values of $22.7 \%, 21.0 \%, 16.2 \%$ and $15.4 \%$, respectively. The relatively high $\mathrm{F}_{\text {is }}$ values for $\mathrm{BR}$ and $\mathrm{W}$ were also expected since these strains have fairly low numbers of animals and are therefore more prone to inbreeding.

For the Nguni, average heterozygosity values of $35.4 \%$ and $36.2 \%$ for NB and B respectively indicated a favourable genetic variation within the two populations. The very low genetic distance value (D) of 0.089 (maximum $=1.0 ; \mathrm{Nei}, 1978$ ) shows that genetic similarity exists between the two subpopulations, hence no dendrogram was obtained. The rate of inbreeding, $\mathrm{F}_{\text {is, }}$ for $\mathrm{B}$ and NB was $53.8 \%$ and $10.1 \%$ respectively, which is in accordance with the fact that Bartlow herds were genetically more isolated and inbred than NB herds.

Growth performance and carcass characteristics are presented in Tables 2 and 3. The $\mathrm{W}$ strain of the Bonsmara gained live weight significantly less efficiently and at a slower rate (non-significant) than the other strains, in particular $\mathrm{T}$ and $\mathrm{R}$ (Table 2). Similar trends were found for carcass and meat gain, with differences between T/R and $\mathrm{W}$ of more than $30 \%$ for carcass and meat growth rate and $20 \%$ for efficiency of carcass and meat gain. $\mathrm{T}$ and $\mathrm{R}$ also evidenced a tendency for higher total carcass fat yield and subsequent lower muscle yield compared to W (adjusted for carcass SCF; Table 3). T and E tended to yield more total carcass weight (2.3\%) and meat (1.9\%) in the high-priced cuts compared to W and BR (Table 3). $\mathrm{BR}$, being the most unrelated subpopulation, had lower hindquarter compactness (conformation) measurements than $\mathrm{E}$ and also tended to have the smallest eye muscle area of all the strains. 


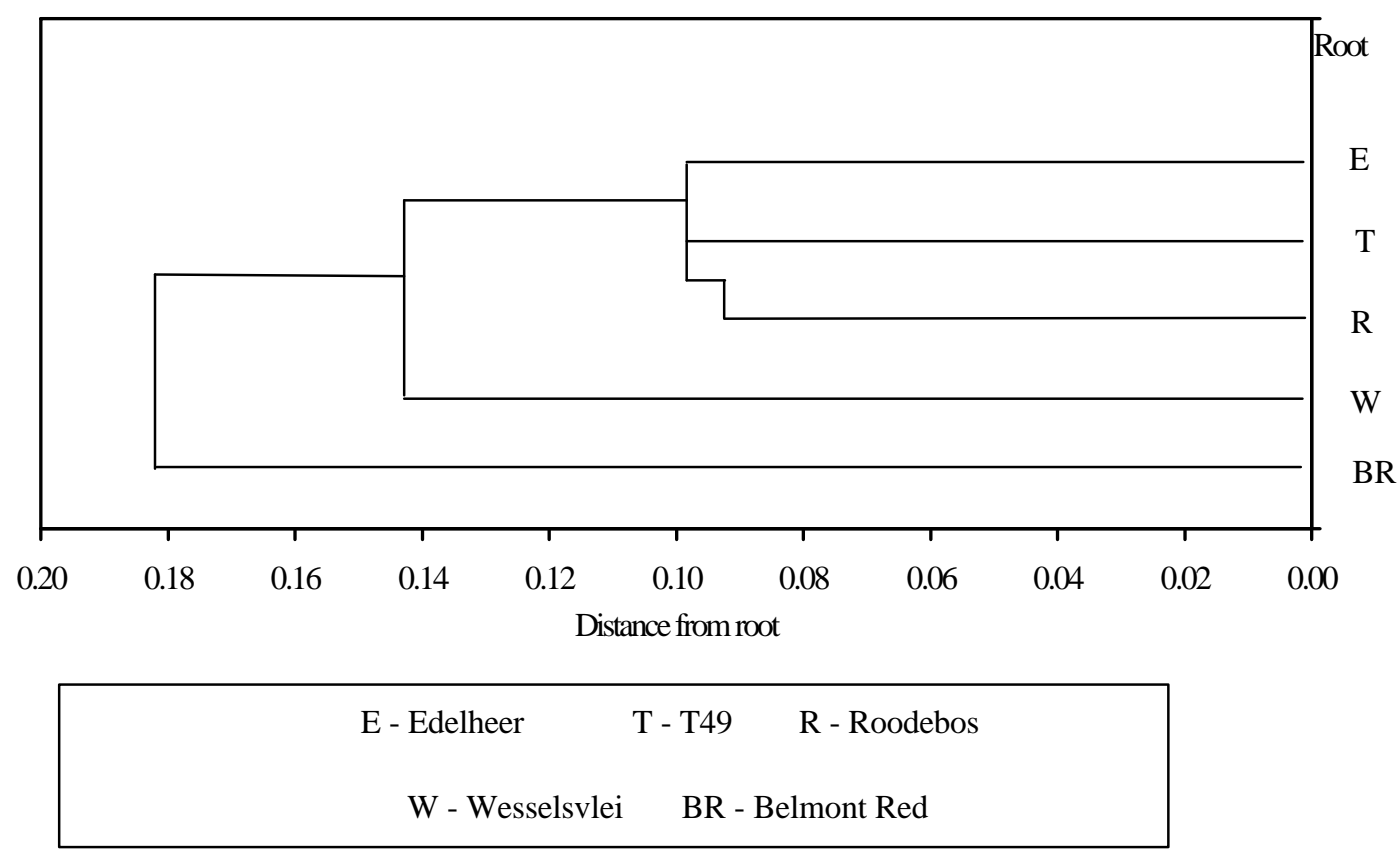

Figure 2 Dendrogram obtained from Nei's distance (1978) for the different Bonsmara strains

Table 2 Adjusted means (s.e. in parentheses) for growth performance of five Bonsmara strains and two Nguni subpopulations

\begin{tabular}{|c|c|c|c|c|c|c|c|c|c|}
\hline & \multicolumn{6}{|c|}{ Bonsmara } & \multicolumn{3}{|c|}{ Nguni } \\
\hline & $\mathrm{E}$ & $\mathrm{T}$ & $\mathrm{W}$ & $\mathrm{BR}$ & $\mathrm{R}$ & Covariate & $\mathrm{B}$ & NB & Covariate \\
\hline \multicolumn{10}{|l|}{$\begin{array}{l}\text { Average daily gain: } \\
\text { (kg/day) }\end{array}$} \\
\hline Live & $\begin{array}{c}1.35 \\
(0.06)\end{array}$ & $\begin{array}{c}1.47 \\
(0.06)\end{array}$ & $\begin{array}{c}1.28 \\
(0.06)\end{array}$ & $\begin{array}{l}1.35 \\
(0.06)\end{array}$ & $\begin{array}{c}1.51 \\
(0.06)\end{array}$ & NS & $\begin{array}{c}1.09 \\
(0.03)\end{array}$ & $\begin{array}{c}1.08 \\
(0.03)\end{array}$ & NS \\
\hline Carcass & $\begin{array}{l}0.87^{b} \\
(0.03)\end{array}$ & $\begin{array}{l}0.90^{\mathrm{b}} \\
(0.04)\end{array}$ & $\begin{array}{l}0.69^{a} \\
(0.05)\end{array}$ & $\begin{array}{l}0.89^{\mathrm{b}} \\
(0.04)\end{array}$ & $\begin{array}{l}0.94^{\mathrm{b}} \\
(0.05)\end{array}$ & 2 & $\begin{array}{c}0.65 \\
(0.02)\end{array}$ & $\begin{array}{c}0.61 \\
(0.03)\end{array}$ & NS \\
\hline Meat & $\begin{array}{l}0.64^{\mathrm{ab}} \\
(0.03)\end{array}$ & $\begin{array}{c}0.69^{\mathrm{b}} \\
(0.03)\end{array}$ & $\begin{array}{c}0.52^{\mathrm{a}} \\
(0.04)\end{array}$ & $\begin{array}{l}0.68^{\mathrm{b}} \\
(0.03)\end{array}$ & $\begin{array}{c}0.71^{\mathrm{b}} \\
(0.04)\end{array}$ & 2 & $\begin{array}{c}0.46 \\
(0.02)\end{array}$ & $\begin{array}{c}0.43 \\
(0.02)\end{array}$ & NS \\
\hline \multicolumn{10}{|c|}{$\begin{array}{l}\text { Feed conversion ratio: } \\
\text { (kg feed / kg gain) }\end{array}$} \\
\hline Live & $\begin{array}{l}6.71^{\mathrm{ab}} \\
(0.24)\end{array}$ & $\begin{array}{c}6.21^{\mathrm{a}} \\
(0.24)\end{array}$ & $\begin{array}{c}7.28^{b} \\
(0.24)\end{array}$ & $\begin{array}{l}6.75^{\mathrm{ab}} \\
(0.24)\end{array}$ & $\begin{array}{l}6.12^{\mathrm{a}} \\
(0.24)\end{array}$ & NS & $\begin{array}{c}6.51 \\
(0.16)\end{array}$ & $\begin{array}{c}6.65 \\
(0.16)\end{array}$ & 1 \\
\hline Carcass & $\begin{array}{l}10.11^{\mathrm{a}} \\
(0.38)\end{array}$ & $\begin{array}{l}9.29^{a} \\
(0.38)\end{array}$ & $\begin{array}{l}11.72^{b} \\
(0.38)\end{array}$ & $\begin{array}{c}10.28^{\mathrm{ab}} \\
(0.38)\end{array}$ & $\begin{array}{l}9.62^{a} \\
(0.38)\end{array}$ & NS & $\begin{array}{l}9.82^{\mathrm{a}} \\
(0.27)\end{array}$ & $\begin{array}{l}11.42^{\mathrm{b}} \\
(0.27)\end{array}$ & NS \\
\hline Meat & $\begin{array}{l}14.2^{\mathrm{ab}} \\
(0.6)\end{array}$ & $\begin{array}{l}12.5^{\mathrm{a}} \\
(0.5)\end{array}$ & $\begin{array}{l}15.2^{\mathrm{b}} \\
(0.6)\end{array}$ & $\begin{array}{l}13.5^{\mathrm{ab}} \\
(0.6)\end{array}$ & $\begin{array}{l}13.2^{a b} \\
(0.6)\end{array}$ & 1 & $\begin{array}{l}14.2^{\mathrm{a}} \\
(0.5)\end{array}$ & $\begin{array}{l}16.3^{\mathrm{b}} \\
(0.5)\end{array}$ & NS \\
\hline Days on feed & $\begin{array}{l}137.1 \\
(9.9)\end{array}$ & $\begin{array}{l}107.7 \\
(9.1)\end{array}$ & $\begin{array}{l}121.3 \\
(9.8)\end{array}$ & $\begin{array}{l}138.2 \\
(9.7)\end{array}$ & $\begin{array}{l}137.9 \\
(10.6)\end{array}$ & 3 & $\begin{array}{l}122.0 \\
(6.6)\end{array}$ & $\begin{array}{l}124.0 \\
(6.3)\end{array}$ & 1 \\
\hline $\begin{array}{l}\text { Feed intake per day } \\
(\mathrm{kg})\end{array}$ & $\begin{array}{c}8.3 \\
(0.3)\end{array}$ & $\begin{array}{c}8.4 \\
(0.3)\end{array}$ & $\begin{array}{c}8.1 \\
(0.4)\end{array}$ & $\begin{array}{c}8.7 \\
(0.3)\end{array}$ & $\begin{array}{c}8.8 \\
(0.5)\end{array}$ & 3 & $\begin{array}{c}6.5 \\
(0.2)\end{array}$ & $\begin{array}{c}6.9 \\
(0.2)\end{array}$ & NS \\
\hline
\end{tabular}


For the Nguni, no significant differences were found for ADG, although B gained carcass and meat significantly more efficiently than NB. No significant differences were found between the Nguni groups for any carcass trait (Table 3), although B tended to yield more muscle and less total carcass fat than NB.

Marshall (1994) quoted positive correlations between post weaning growth (days on feed were constant) and carcass weight $(r=0.89)$, eye muscle area $(r=0.48)$ and fat trim percentage $(r=0.15)$, while Jones et al. (1984) and Southgate et al. (1982) found that larger, later maturing animal types gained live and muscle weight significantly faster than smaller animals when adjustments were made to a constant SCF endpoint. Furthermore, Kempster et al. (1976) and De Bruyn (1991) found significantly higher intermuscular fat (IMF) yields for later maturing breed types compared to smaller earlier maturing types compared at a common SCF level, while Kempster et al. (1981) and Kempster et al. (1988) reported that later maturing types were favoured in saleable yield in the high-priced cuts when compared with earlier maturing breed types at a common SCF level. According to these researchers, therefore, maturity type differences (differences in carcass weight at a common carcass condition) would have been expected between the Bonsmara strains (especially between $\mathrm{T}$ and $\mathrm{W}$ ) and between the Nguni subpopulations. However, no significant differences in carcass weight were found between subpopulations within each breed at a common level of SCF, which indicates that the differences found between subpopulations were not related to maturity type differences. In support of the differences in growth and carcass characteristics, Korver et al. (1987) reported carcass composition differences between animals even after adjusting for maturity, while Kempster et al. (1982) found differences in muscle-to-bone ratios for beef breeds of similar maturity types such as the Charolais and Devon.

Table 3 Adjusted means (s.e. in parentheses) for carcass characteristics of five Bonsmara strains and two Nguni subpopulations

\begin{tabular}{|c|c|c|c|c|c|c|c|c|c|}
\hline & \multicolumn{6}{|c|}{ Bonsmara } & \multicolumn{3}{|c|}{ Nguni } \\
\hline & $\mathrm{E}$ & $\mathrm{T}$ & W & $\mathrm{BR}$ & $\mathrm{R}$ & Covariate & B & NB & Covariate \\
\hline$\overline{\text { Slaughter weight }(\mathrm{kg})}$ & $\begin{array}{l}419.3 \\
(2.7)\end{array}$ & $\begin{array}{l}416.1 \\
(2.5)\end{array}$ & $\begin{array}{l}412.1 \\
(3.4)\end{array}$ & $\begin{array}{c}412.1 \\
(2.6)\end{array}$ & $\begin{array}{l}420.5 \\
(4.0)\end{array}$ & & $\begin{array}{l}295.1 \\
(1.7)\end{array}$ & $\begin{array}{l}295.9 \\
(1.6)\end{array}$ & \\
\hline Carcass weight (kg) & $\begin{array}{c}240.8 \\
(2.3)\end{array}$ & $\begin{array}{c}241.2 \\
(2.2)\end{array}$ & $\begin{array}{c}241.8 \\
(2.9)\end{array}$ & $\begin{array}{c}236.2 \\
(2.3)\end{array}$ & $\begin{array}{c}239.3 \\
(3.4)\end{array}$ & 3 & $\begin{array}{c}168.5 \\
(1.2)\end{array}$ & $\begin{array}{l}167.8 \\
(1.1)\end{array}$ & 1 \\
\hline Dressing percentage ${ }^{4}$ & $\begin{array}{l}57.2 \\
(0.5)\end{array}$ & $\begin{array}{l}57.8 \\
(0.4)\end{array}$ & $\begin{array}{l}57.8 \\
(0.5)\end{array}$ & $\begin{array}{l}57.4 \\
(0.5)\end{array}$ & $\begin{array}{l}56.9 \\
(0.5)\end{array}$ & 1 & $\begin{array}{l}57.0 \\
(0.5)\end{array}$ & $\begin{array}{l}56.7 \\
(0.5)\end{array}$ & 1 \\
\hline Carcass compactness & $\begin{array}{c}0.94 \\
(0.01)\end{array}$ & $\begin{array}{c}0.93 \\
(0.01)\end{array}$ & $\begin{array}{c}0.93 \\
(0.01)\end{array}$ & $\begin{array}{c}0.94 \\
(0.01)\end{array}$ & $\begin{array}{c}0.91 \\
(0.01)\end{array}$ & 1 & $\begin{array}{c}0.74 \\
(0.01)\end{array}$ & $\begin{array}{c}0.74 \\
(0.01)\end{array}$ & 1 \\
\hline Hindquarter compactness & $\begin{array}{c}0.79^{\mathrm{a}} \\
(0.01)\end{array}$ & $\begin{array}{l}0.78^{\mathrm{ab}} \\
(0.01)\end{array}$ & $\begin{array}{l}0.76^{\mathrm{ab}} \\
(0.01)\end{array}$ & $\begin{array}{l}0.74^{\mathrm{b}} \\
(0.02)\end{array}$ & $\begin{array}{l}0.78^{\mathrm{ab}} \\
(0.01)\end{array}$ & 3 & $\begin{array}{c}0.59 \\
(0.01)\end{array}$ & $\begin{array}{c}0.58 \\
(0.01)\end{array}$ & 1 \\
\hline Eye muscle area $\left(\mathrm{cm}^{2}\right)$ & $\begin{array}{l}83.2 \\
(2.8)\end{array}$ & $\begin{array}{l}78.4 \\
(2.5)\end{array}$ & $\begin{array}{l}79.4 \\
(2.6)\end{array}$ & $\begin{array}{l}75.9 \\
(2.7)\end{array}$ & $\begin{array}{l}84.8 \\
(3.0)\end{array}$ & 1 & $\begin{array}{l}70.2 \\
(2.4)\end{array}$ & $\begin{array}{l}68.1 \\
(2.3)\end{array}$ & 1 \\
\hline Carcass composition and tissu & e distrib & ion: & & & & & & & \\
\hline Meat & $\begin{array}{c}79.9 \\
(0.33)\end{array}$ & $\begin{array}{c}79.8 \\
(0.31)\end{array}$ & $\begin{array}{c}79.7 \\
(0.32)\end{array}$ & $\begin{array}{l}79.6 \\
(0.32)\end{array}$ & $\begin{array}{c}80.1 \\
(0.36)\end{array}$ & 1 & $\begin{array}{c}78.8 \\
(0.30)\end{array}$ & $\begin{array}{c}78.9 \\
(0.29)\end{array}$ & 1 \\
\hline Muscle(\%) & $\begin{array}{l}70.0 \\
(0.7)\end{array}$ & $\begin{array}{l}67.7 \\
(0.7)\end{array}$ & $\begin{array}{l}70.0 \\
(0.7)\end{array}$ & $\begin{array}{l}68.6 \\
(0.7)\end{array}$ & $\begin{array}{l}68.4 \\
(0.7)\end{array}$ & NS & $\begin{array}{c}69.2 \\
(0.81)\end{array}$ & $\begin{array}{c}68.0 \\
(0.81)\end{array}$ & NS \\
\hline Intermuscular fat $(\%)$ & $\begin{array}{c}10.1 \\
(0.73)\end{array}$ & $\begin{array}{c}12.2 \\
(0.64)\end{array}$ & $\begin{array}{c}10.3 \\
(0.67)\end{array}$ & $\begin{array}{c}11.4 \\
(0.70)\end{array}$ & $\begin{array}{l}11.4 \\
(0.75)\end{array}$ & 1 & $\begin{array}{c}9.8 \\
(0.66)\end{array}$ & $\begin{array}{l}11.0 \\
(0.66)\end{array}$ & 2 \\
\hline Total carcass fat $(\%)$ & $\begin{array}{c}15.0 \\
(0.68)\end{array}$ & $\begin{array}{c}17.4 \\
(0.62)\end{array}$ & $\begin{array}{l}14.8 \\
(0.65)\end{array}$ & $\begin{array}{l}16.3 \\
(0.66)\end{array}$ & $\begin{array}{l}16.6 \\
(0.73)\end{array}$ & 1 & $\begin{array}{l}14.9 \\
(0.93)\end{array}$ & $\begin{array}{l}16.6 \\
(0.89)\end{array}$ & 1 \\
\hline Bone $(\%)$ & $\begin{array}{l}15.3 \\
(0.3)\end{array}$ & $\begin{array}{l}15.3 \\
(0.3)\end{array}$ & $\begin{array}{l}15.4 \\
(0.3)\end{array}$ & $\begin{array}{l}15.5 \\
(0.3)\end{array}$ & $\begin{array}{l}15.0 \\
(0.4)\end{array}$ & 1 & $\begin{array}{l}16.0 \\
(0.3)\end{array}$ & $\begin{array}{l}15.9 \\
(0.3)\end{array}$ & 1 \\
\hline $\begin{array}{l}\text { Total yield in high-priced } \\
\text { cuts }(\%)^{5}\end{array}$ & $\begin{array}{l}39.4 \\
(0.3)\end{array}$ & $\begin{array}{l}39.7 \\
(0.2)\end{array}$ & $\begin{array}{l}38.8 \\
(0.2)\end{array}$ & $\begin{array}{l}38.8 \\
(0.2)\end{array}$ & $\begin{array}{l}39.0 \\
(0.3)\end{array}$ & 1 & $\begin{array}{l}40.8 \\
(0.3)\end{array}$ & $\begin{array}{l}40.7 \\
(0.2)\end{array}$ & 1 \\
\hline $\begin{array}{l}\text { Meat yield in high-priced } \\
\text { cuts }(\%)^{5}\end{array}$ & $\begin{array}{l}42.2 \\
(0.3)\end{array}$ & $\begin{array}{l}42.3 \\
(0.3)\end{array}$ & $\begin{array}{l}41.6 \\
(0.4)\end{array}$ & $\begin{array}{l}41.6 \\
(0.3)\end{array}$ & $\begin{array}{l}41.9 \\
(0.4)\end{array}$ & 3 & $\begin{array}{l}43.5 \\
(0.3)\end{array}$ & $\begin{array}{l}43.5 \\
(0.3)\end{array}$ & 1 \\
\hline
\end{tabular}

Row means without common superscripts differ $(\mathrm{P}<0.05) ;{ }^{1}$ covariate SCF percentage was significant $(\mathrm{P}<$
$0.05)$ and means were adjusted to $5.2 \%$ and $4.8 \%$ SCF for Nguni and Bonsmara groups respectively; ${ }^{2}$ covariate starting weight was significant $(\mathrm{P}<0.05) ;{ }^{3}$ both covariates were significant $(\mathrm{P}<0.05)$; ${ }^{4}$ based on fasted live weight; ${ }^{5}$ total yield (high-priced, forequarter, ventral, shin) expressed relative to total carcass weight. Meat yield was expressed relative to total meat yield 
Meat quality characteristics are presented in Table 4. Sensory panel scores and shear force values showed a $17 \%$ advantage in meat tenderness for $\mathrm{W}$ compared to $\mathrm{T}$, and a $9 \%$ advantage (sensory tenderness) for B compared to NB. These differences coincided with a $17 \%$ advantage in MFI for $\mathrm{W}$ compared to T and a $10 \%$ advantage for B compared to NB for muscle aged for 7 days. MFI was used to measure the degree of fragmentation of myofibrils caused by proteolysis (Olson \& Parish, 1997). Although Olsson \& Tornberg (1992) did not regard fragmentation of myofibrils as a crucial factor for muscle tenderness, Culler et al. (1978) reported that MFI accounted for 50\% of the variation in loin steak tenderness and regarded myofibril fragmentation as a more important effector of tenderness than sarcomere length or collagen solubility (similar age). In addition, Crouse et al. (1991) and Seideman et al. (1987) reported correlation coefficients of 0.53 and 0.60 between MFI and sensory tenderness for muscle aged over a period of one to seven days, compared to $0.40(\mathrm{P}<0.001)$ and 0.47 for the Bonsmara and Nguni respectively in the current study (Tables 5 and 6).

In addition to MFI differences, muscle fibre type differences in respect of size as well as ratio occurred between the Bonsmara groups, while no significant differences were found between the two Nguni groups. Lawrie (1977) classified muscle fibres into two broad groups, viz. red and white fibres, while an alpha (also called intermediate) and beta fibres have been identified within the red fibre group. Fibre type and dimension are characteristic of breed and sex, and are influenced by age and diet (Seideman et al., 1986). Intermediate muscle fibre area of $\mathrm{E}$ and white muscle fibre area of $\mathrm{E}$ and $\mathrm{R}$ were respectively $25 \%$ and $34 \%$ larger than that of BR, while the percentage white fibre of $\mathrm{E}$ tended to be higher than that of $\mathrm{W}$. These differences did not seem to have any direct effect on differences in muscle tenderness, despite a correlation of -0.45 ( $\mathrm{P}<0.001$; Table 5) between white muscle fibre percentage and sensory tenderness for the Bonsmara. Calkins et al. (1981), who found a negative relationship between white fibre area and tenderness, but a positive relationship between red fibre area and tenderness illustrated the effect of variation in muscle fibre characteristics. Calkins et al. (1981) and Dreyer et al. (1977) also reported that an increased percentage of white fibres could be associated with a decrease in sensory tenderness, which is in agreement with Table 5. The lack of an association between fibre type and muscle tenderness in the current trial can probably be attributed to the fact that a complex sequence of events take place when muscle changes to meat. These events are influenced by a variety of physiological and physical interventions that have a major bearing on the ultimate meat quality (Devine \& Chrystall, 1992). In this study the fragmentation of muscle per se probably had the largest effect on this process and probably masked the effect of other factors on meat tenderness. The significant negative correlations between MFI and white fibre percentage for both breeds (Tables 5 and 6) did, however, confirm the negative effect of white fibres on tenderness. Seideman et al. (1987) reported that myofibrillar fragmentation per se explained more of the variation in tenderness than any fibre type characteristic (size or ratio), while Crouse et al. (1991) showed that the effect of fibre type ratio and size on variation in tenderness was limited to three days of ageing, whereupon the effect diminished and fragmentation of fibres took place independently of fibre type variation. Meat in the present study was aged for seven days. Significant differences in sarcomere length between B and NB had no effect on meat tenderness, probably the reasons discussed above. Although the difference in tenderness between B and NB for the Nguni corresponded with a difference in marbling $(\mathrm{P}>0.05)$ between these groups, marbling had low correlations with tenderness in Nguni meat $(r=0.31 ; \mathrm{P}>0.05)$. In addition, the marbling levels were less than $1 \%$, while Savell \& Cross (1988) argued that 3\% marbling is the minimum level required to ensure acceptable palatability for the consumer in the United States of America. 
Table 4 Adjusted means (s.e. in parentheses) for sensory attributes and muscle quality characteristics of five Bonsmara strains and two Nguni subpopulations

\begin{tabular}{|c|c|c|c|c|c|c|c|c|c|}
\hline & \multicolumn{5}{|c|}{ Bonsmara } & \multicolumn{4}{|c|}{ Nguni } \\
\hline & $\mathrm{E}$ & $\mathrm{T}$ & $\mathrm{W}$ & BR & $\mathrm{R}$ & Cov. & B & NB & Cov. \\
\hline \multicolumn{10}{|l|}{ Sensory attributes: } \\
\hline Aroma & $\begin{array}{c}6.1 \\
(0.1)\end{array}$ & $\begin{array}{c}6.2 \\
(0.1)\end{array}$ & $\begin{array}{c}6.2 \\
(0.1)\end{array}$ & $\begin{array}{c}6.1 \\
(0.1)\end{array}$ & $\begin{array}{c}6.2 \\
(0.1)\end{array}$ & NS & $\begin{array}{c}6.1 \\
(0.1)\end{array}$ & $\begin{array}{c}6.0 \\
(0.1)\end{array}$ & NS \\
\hline Juiciness & $\begin{array}{l}4.7^{\mathrm{a}} \\
(0.1)\end{array}$ & $\begin{array}{l}5.1^{\mathrm{b}} \\
(0.1)\end{array}$ & $\begin{array}{l}4.9^{\mathrm{ab}} \\
(0.1)\end{array}$ & $\begin{array}{l}4.8^{\mathrm{ab}} \\
(0.1)\end{array}$ & $\begin{array}{l}5.0^{\mathrm{ab}} \\
(0.1)\end{array}$ & NS & $\begin{array}{l}5.6 \\
(0.1)\end{array}$ & $\begin{array}{c}5.4 \\
(0.1)\end{array}$ & NS \\
\hline Tenderness & $\begin{array}{l}5.0^{\mathrm{ab}} \\
(0.2)\end{array}$ & $\begin{array}{l}4.6^{\mathrm{a}} \\
(0.2)\end{array}$ & $\begin{array}{l}5.4^{\mathrm{b}} \\
(0.2)\end{array}$ & $\begin{array}{l}4.8^{\mathrm{ab}} \\
(0.2)\end{array}$ & $\begin{array}{l}5.0^{\mathrm{ab}} \\
(0.2)\end{array}$ & NS & $\begin{array}{l}6.1^{\mathrm{a}} \\
(0.2)\end{array}$ & $\begin{array}{l}5.6^{\mathrm{b}} \\
(0.2)\end{array}$ & NS \\
\hline Residual tissue & $\begin{array}{l}4.8 \\
(0.1)\end{array}$ & $\begin{array}{l}4.6 \\
(0.1)\end{array}$ & $\begin{array}{l}5.0 \\
(0.1)\end{array}$ & $\begin{array}{l}4.6 \\
(0.1)\end{array}$ & $\begin{array}{c}5.0 \\
(0.1)\end{array}$ & NS & $\begin{array}{l}6.0^{\mathrm{a}} \\
(0.1)\end{array}$ & $\begin{array}{l}5.5^{\mathrm{b}} \\
(0.1)\end{array}$ & NS \\
\hline Flavour & $\begin{array}{c}5.8 \\
(0.1)\end{array}$ & $\begin{array}{l}5.8 \\
(0.1)\end{array}$ & $\begin{array}{l}5.9 \\
(0.1)\end{array}$ & $\begin{array}{c}5.7 \\
(0.1)\end{array}$ & $\begin{array}{c}5.9 \\
(0.1)\end{array}$ & NS & $\begin{array}{l}6.0 \\
(0.1)\end{array}$ & $\begin{array}{l}5.9 \\
(0.1)\end{array}$ & NS \\
\hline $\begin{array}{l}\text { Shear force } \\
\text { measurement }\end{array}$ & $\begin{array}{l}92.3 \\
(4.0)\end{array}$ & $\begin{array}{l}101.7 \\
(4.0)\end{array}$ & $\begin{array}{l}87.2 \\
(4.0)\end{array}$ & $\begin{array}{l}90.4 \\
(4.0)\end{array}$ & $\begin{array}{l}89.4 \\
(4.0)\end{array}$ & NS & $\begin{array}{l}87.5 \\
(3.4)\end{array}$ & $\begin{array}{l}94.7 \\
(3.4)\end{array}$ & NS \\
\hline \multirow{2}{*}{$\begin{array}{l}(\mathrm{N} / 2.5 \mathrm{~cm} \varnothing) \\
\text { Total cooking loss }(\%)\end{array}$} & & & & & & & & & \\
\hline & $\begin{array}{l}23.8 \\
(0.6)\end{array}$ & $\begin{array}{l}24.6 \\
(0.6)\end{array}$ & $\begin{array}{l}23.9 \\
(0.6)\end{array}$ & $\begin{array}{l}23.8 \\
(0.6)\end{array}$ & $\begin{array}{l}23.4 \\
(0.6)\end{array}$ & 1 & $\begin{array}{l}22.3 \\
(0.6)\end{array}$ & $\begin{array}{l}21.7 \\
(0.6)\end{array}$ & NS \\
\hline Collagen content & $\begin{array}{c}1.71 \\
(0.08)\end{array}$ & $\begin{array}{c}1.42 \\
(0.08)\end{array}$ & $\begin{array}{l}1.65 \\
(0.08)\end{array}$ & $\begin{array}{l}1.68 \\
(0.08)\end{array}$ & $\begin{array}{c}1.58 \\
(0.08)\end{array}$ & NS & $\begin{array}{c}1.98 \\
(0.10)\end{array}$ & $\begin{array}{c}1.99 \\
(0.10)\end{array}$ & NS \\
\hline Collagen solubility (\%) & $\begin{array}{l}28.3^{\mathrm{c}} \\
(1.0)\end{array}$ & $\begin{array}{l}9.59^{\mathrm{a}} \\
(0.98)\end{array}$ & $\begin{array}{l}12.0^{\mathrm{a}} \\
(0.9)\end{array}$ & $\begin{array}{l}14.2^{\mathrm{a}} \\
(1.0)\end{array}$ & $\begin{array}{l}18.8^{\mathrm{b}} \\
(1.0)\end{array}$ & 3 & $\begin{array}{l}19.8 \\
(1.2)\end{array}$ & $\begin{array}{l}21.7 \\
(1.2)\end{array}$ & NS \\
\hline Marbling (\%) & $\begin{array}{c}1.01 \\
(0.17)\end{array}$ & $\begin{array}{l}1.16 \\
(0.14)\end{array}$ & $\begin{array}{c}0.84 \\
(0.13)\end{array}$ & $\begin{array}{c}0.81 \\
(0.12)\end{array}$ & $\begin{array}{c}0.95 \\
(0.16)\end{array}$ & 1 & $\begin{array}{c}0.75 \\
(0.08)\end{array}$ & $\begin{array}{c}0.51 \\
(0.08)\end{array}$ & NS \\
\hline \multicolumn{10}{|l|}{ Muscle fibre area $\left(\mu \mathrm{m}^{2}\right)$} \\
\hline Red fibre & $\begin{array}{l}2744 \\
(174)\end{array}$ & $\begin{array}{l}2377 \\
(173)\end{array}$ & $\begin{array}{l}2513 \\
(159)\end{array}$ & $\begin{array}{l}2532 \\
(159)\end{array}$ & $\begin{array}{l}2930 \\
(1.7)\end{array}$ & 1 & $\begin{array}{l}2998 \\
(164)\end{array}$ & $\begin{array}{l}2904 \\
(157)\end{array}$ & 1 \\
\hline Intermediate fibre & $\begin{array}{l}3618^{\mathrm{b}} \\
(174)\end{array}$ & $\begin{array}{c}3151^{a b} \\
(174)\end{array}$ & $\begin{array}{c}3071^{\mathrm{ab}} \\
(174)\end{array}$ & $\begin{array}{l}2877^{\mathrm{a}} \\
(174)\end{array}$ & $\begin{array}{c}3196^{\mathrm{ab}} \\
(174)\end{array}$ & NS & $\begin{array}{l}3458 \\
(165)\end{array}$ & $\begin{array}{l}3421 \\
(165)\end{array}$ & NS \\
\hline White fibre & $\begin{array}{l}6538^{b} \\
(327)\end{array}$ & $\begin{array}{l}5844^{\mathrm{ab}} \\
(325)\end{array}$ & $\begin{array}{l}5273^{\mathrm{ab}} \\
(299)\end{array}$ & $\begin{array}{l}4870^{\mathrm{a}} \\
(299)\end{array}$ & $\begin{array}{l}6474^{b} \\
(351)\end{array}$ & 1 & $\begin{array}{l}5247 \\
(244)\end{array}$ & $\begin{array}{l}5165 \\
(244)\end{array}$ & NS \\
\hline \multicolumn{10}{|l|}{ Muscle fibre ratio: (\%) } \\
\hline Red fibre & $\begin{array}{l}33.6 \\
(0.5)\end{array}$ & $\begin{array}{l}32.8 \\
(0.5)\end{array}$ & $\begin{array}{l}33.5 \\
(0.5)\end{array}$ & $\begin{array}{l}34.0 \\
(0.5)\end{array}$ & $\begin{array}{c}34.4 \\
(0.6)\end{array}$ & 1 & $\begin{array}{l}34.4 \\
(0.4)\end{array}$ & $\begin{array}{l}34.4 \\
(0.4)\end{array}$ & 1 \\
\hline Intermediate fibre & $\begin{array}{l}24.7 \\
(0.6)\end{array}$ & $\begin{array}{l}26.2 \\
(0.6)\end{array}$ & $\begin{array}{l}26.5 \\
(0.6)\end{array}$ & $\begin{array}{l}26.7 \\
(0.6)\end{array}$ & $\begin{array}{l}26.0 \\
(0.7)\end{array}$ & 1 & $\begin{array}{l}30.5 \\
(0.5)\end{array}$ & $\begin{array}{l}30.0 \\
(0.4)\end{array}$ & 1 \\
\hline White fibre & $\begin{array}{l}41.7 \\
(0.6)\end{array}$ & $\begin{array}{l}41.0 \\
(0.6)\end{array}$ & $\begin{array}{l}39.9 \\
(0.6)\end{array}$ & $\begin{array}{c}39.3 \\
(0.6)\end{array}$ & $\begin{array}{l}39.6 \\
(0.7)\end{array}$ & 1 & $\begin{array}{l}35.1 \\
(0.6)\end{array}$ & $\begin{array}{l}35.7 \\
(0.6)\end{array}$ & 1 \\
\hline Sarcomere length $(\mu \mathrm{m})$ & $\begin{array}{c}1.77 \\
(0.03)\end{array}$ & $\begin{array}{c}1.77 \\
(0.03)\end{array}$ & $\begin{array}{c}1.80 \\
(0.03)\end{array}$ & $\begin{array}{c}1.83 \\
(0.03)\end{array}$ & $\begin{array}{c}1.81 \\
(0.03)\end{array}$ & NS & $\begin{array}{c}1.90^{\mathrm{a}} \\
(0.03)\end{array}$ & $\begin{array}{l}1.84^{\mathrm{b}} \\
(0.03)\end{array}$ & 1 \\
\hline \multicolumn{10}{|c|}{ Myofibrillar fragmentation index: } \\
\hline $\begin{array}{l}\text { Myofibrillar fragment } \\
\text { MFI } 1 \text { day p.m. }\end{array}$ & $\begin{array}{l}86.5 \\
(6.4)\end{array}$ & $\begin{array}{l}80.4 \\
(5.9)\end{array}$ & $\begin{array}{l}84.0 \\
(6.2)\end{array}$ & $\begin{array}{l}83.6 \\
(6.3)\end{array}$ & $\begin{array}{l}94.4 \\
(7.0)\end{array}$ & 1 & $\begin{array}{c}103.5^{\mathrm{a}} \\
(4.4)\end{array}$ & $\begin{array}{l}86.1^{\mathrm{b}} \\
(4.4)\end{array}$ & NS \\
\hline MFI 7 days p.m. & $\begin{array}{l}114.9 \\
(6.6)\end{array}$ & $\begin{array}{c}100.3 \\
(6.6)\end{array}$ & $\begin{array}{l}117.3 \\
(6.6)\end{array}$ & $\begin{array}{c}110.8 \\
(6.6)\end{array}$ & $\begin{array}{c}102.5 \\
(6.6)\end{array}$ & NS & $\begin{array}{c}141.2^{\mathrm{a}} \\
(3.6)\end{array}$ & $\begin{array}{c}128.9^{\mathrm{b}} \\
(3.5)\end{array}$ & 1 \\
\hline MFI 14 days p.m. & $\begin{array}{l}110.9 \\
(6.4)\end{array}$ & $\begin{array}{l}110.5 \\
(6.4)\end{array}$ & $\begin{array}{l}121.5 \\
(6.4)\end{array}$ & $\begin{array}{l}125.1 \\
(6.4)\end{array}$ & $\begin{array}{l}111.2 \\
(6.4)\end{array}$ & NS & $\begin{array}{c}145.3 \\
(4.1)\end{array}$ & $\begin{array}{c}135.5 \\
(3.9)\end{array}$ & 1 \\
\hline
\end{tabular}

a,b,c,d,e Row means without common superscripts differ $(\mathrm{P}<0.05)$; ${ }^{1}$ covariate SCF percentage was significant $(\mathrm{P}<$ 0.05), means were adjusted to $5.2 \%$ and $4.8 \%$ SCF for Nguni and Bonsmara groups respectively; ${ }^{2}$ covariate starting weight was significant $(\mathrm{P}<0.05) ;{ }^{3}$ both covariates were significant $(\mathrm{P}<0.05)$; Cov: covariate 
Table 5 Pairwise correlation coefficients for growth performance, meat quality and muscle characteristics of the Bonsmara ${ }^{1}$

\begin{tabular}{|c|c|c|c|c|c|c|c|c|c|c|c|c|c|c|}
\hline & 1. & 2. & 3. & 4. & 5. & 6. & 7. & 8. & 9. & 10. & 11. & 12. & 13 & 14. \\
\hline 1. Sensory tenderness & & & & & & & & & & & & & & \\
\hline 2. Shear force & $-0.64 * * *$ & & & & & & & & & & & & & \\
\hline 3. Collagen content & 0.08 & -0.10 & & & & & & & & & & & & \\
\hline 4. Collagen solubility & -0.08 & -0.02 & 0.09 & & & & & & & & & & & \\
\hline 5. Red fibre area & 0.06 & -0.15 & 0.11 & 0.00 & & & & & & & & & & \\
\hline 6. Intermediate fibre area & -0.08 & 0.11 & 0.02 & 0.15 & $0.72 * * *$ & & & & & & & & & \\
\hline 7. White fibre area & -0.10 & 0.03 & -0.02 & 0.18 & $0.65 * * *$ & $0.79 * * *$ & & & & & & & & \\
\hline 8. Red fibre $\%$ & $0.32 *$ & $-0.30 *$ & 0.05 & -0.23 & $0.27 *$ & 0.18 & 0.22 & & & & & & & \\
\hline 9. Intermediate fibre $\%$ & $0.36^{* *}$ & -0.23 & 0.06 & $-0.42 * * *$ & 0.06 & -0.18 & -0.05 & 0.16 & & & & & & \\
\hline 10. White fibre $\%$ & $-0.45 * * *$ & $0.34 * *$ & -0.07 & $0.43 * * *$ & -0.20 & 0.02 & -0.10 & $-0.72 * * *$ & $-0.80 * * *$ & & & & & \\
\hline 11. Sarcomere length & 0.16 & $-0.44 * * *$ & 0.05 & -0.01 & -0.03 & -0.09 & -0.04 & 0.10 & 0.18 & -0.19 & & & & \\
\hline 12. MFI7 & $0.40 * * *$ & $-0.31 *$ & -0.13 & -0.15 & $0.28 *$ & 0.18 & 0.14 & 0.15 & $0.43 * * *$ & $-0.39 * *$ & 0.07 & & & \\
\hline 13. ADG (carcass) & -0.23 & 0.17 & 0.07 & -0.06 & -0.03 & -0.06 & 0.01 & 0.02 & -0.24 & 0.18 & -0.16 & $-0.44 * * *$ & & \\
\hline 14. FCR (carcass) & $0.25^{*}$ & -0.18 & 0.07 & -0.17 & 0.23 & 0.11 & 0.04 & 0.23 & $0.38 * *$ & $-0.41 * * *$ & 0.11 & $0.46^{* * *}$ & $-0.72 * * *$ & \\
\hline 15. Marbling & 0.11 & -0.08 & 0.05 & -0.12 & $0.45^{* * *}$ & $0.26^{*}$ & $0.30 *$ & $0.34 * *$ & 0.15 & $-0.31 *$ & -0.10 & 0.23 & -0.03 & 0.09 \\
\hline
\end{tabular}

${ }^{1}$ Significance of correlations are relative to zero for $n-2$ degrees of freedom; $n=$ number of values for each specific pair of traits; $* \mathrm{P}<0.05 ; * * \mathrm{P}<0.01 ; * * * \mathrm{P}<0.001$

Table 6 Pairwise correlation coefficients for growth performance, meat quality and muscle characteristics of the Nguni ${ }^{1}$

\begin{tabular}{|c|c|c|c|c|c|c|c|c|c|c|c|c|c|c|}
\hline & 1. & 2. & 3. & 4. & 5. & 6. & 7. & 8. & 9. & 10. & 11. & 12. & 13 & 14. \\
\hline 1. Sensory tenderness & & & & & & & & & & & & & & \\
\hline 2. Shear force & $-0.67 * * *$ & & & & & & & & & & & & & \\
\hline 3. Collagen content & -0.01 & 0 & & & & & & & & & & & & \\
\hline 4. Collagen solubility & -0.11 & -0.16 & 0.01 & & & & & & & & & & & \\
\hline 5. Red fibre area & -0.11 & -0.04 & $-0.41 *$ & -0.02 & & & & & & & & & & \\
\hline 6. Intermediate fibre area & -0.07 & -0.07 & -0.19 & -0.05 & $0.81 * * *$ & & & & & & & & & \\
\hline 7. White fibre area & -0.21 & 0.01 & -0.28 & 0.04 & $0.60 * * *$ & $0.81 * * *$ & & & & & & & & \\
\hline 8. Red fibre $\%$ & 0.06 & -0.14 & -0.27 & -0.07 & 0.35 & 0.19 & 0.15 & & & & & & & \\
\hline 9. Intermediate fibre $\%$ & -0.03 & 0.19 & -0.09 & -0.35 & 0.30 & 0.34 & 0.26 & $0.41 * *$ & & & & & & \\
\hline 10. White fibre $\%$ & -0.01 & -0.05 & 0.21 & 0.26 & $-0.38^{*}$ & -0.32 & -0.25 & $-0.81 * * *$ & $-0.87 * * *$ & & & & & \\
\hline 11. Sarcomere length & 0.08 & 0.05 & -0.14 & -0.02 & 0.16 & 0.21 & 0.24 & 0.04 & 0.21 & -0.16 & & & & \\
\hline 12.MFI7 & $0.47 *$ & $-0.47 *$ & -0.15 & 0.13 & 0.04 & -0.01 & 0.12 & $0.36^{*}$ & $0.36^{*}$ & $-0.43^{*}$ & 0.31 & & & \\
\hline 13. ADG (carcass) & 0.24 & 0.06 & 0.13 & -0.07 & $-0.53 * *$ & -0.28 & -0.22 & $-0.52 * *$ & -0.16 & $0.39 *$ & 0.26 & -0.28 & & \\
\hline 14.FCR (carcass) & -0.11 & 0.12 & -0.14 & 0.05 & $0.37 *$ & 0.33 & 0.35 & $0.56^{* *}$ & $0.48^{*}$ & $-0.62 * * *$ & 0.16 & $0.51 * *$ & $-0.54 * *$ & \\
\hline 15. Marbling & 0.31 & -0.31 & -0.11 & 0.17 & -0.18 & -0.17 & -0.20 & -0.01 & 0.03 & -0.01 & -0.13 & 0.04 & 0.15 & -0.20 \\
\hline
\end{tabular}

${ }^{\text {I }}$ Significance of correlations are relative to zero for $n-2$ degrees of freedom; $n=$ number of values for each specific pair of traits; $* \mathrm{P}<0.05 ; * * \mathrm{P}<0.01 ; * * * \mathrm{P}<0.001$

The South African Journal of Animal Science is available online at http://www.sasas.co.za/Sajas.html 
E had a significantly higher collagen solubility than the other strains, while R was superior to $\mathrm{T}$, W and BR. A significant interaction between strain and slaughter group was observed, which indicated that collagen solubility of $\mathrm{E}$ was high at S1, but then declined sharply to levels closer to those of the other strains at S3 (Figure 3). In contrast, W, BR and T did not show any variation in collagen solubility between slaughter groups, while $\mathrm{R}$ was intermediate to $\mathrm{E}$ and the other groups. $\mathrm{T}$ and $\mathrm{W}$, being the most unlike strains with regard to sensory tenderness, were the most similar in collagen solubility. According to Crosley (1994), such collagen solubility differences are expected among animals with large physiological age differences. However, the animals in this trial were all between nine and 12 months of age. Furthermore, Naudé \& Boccard (1973) reported much less variation in collagen solubility between a number of breed crosses slaughtered within the same age class than was observed between the animals in the current trial. Their data showed values for collagen solubility ranging between $32 \%$ and $34 \%$, which are much higher than the values recorded in the current trial.

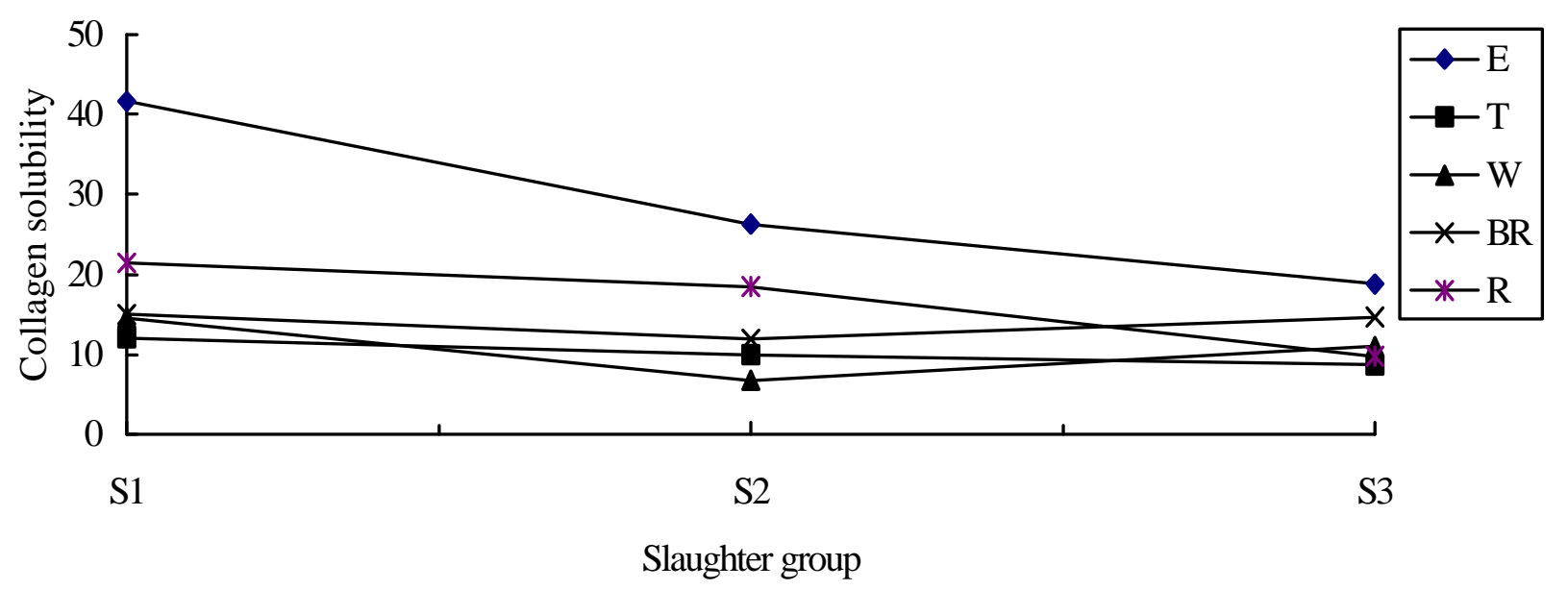

Figure 3 Interaction between slaughter group and subpopulation for collagen solubility in the Bonsmara

There was no significant correlation between shear force measurement or sensory tenderness and collagen solubility, which is in contrast to the findings of Crouse et al. (1985). It is proposed that other muscle properties had a greater influence on sensory tenderness than collagen alone. Seideman et al. (1987) reported that MFI and percentage red muscle fibre contributed towards differences in sensory tenderness and shear force, while collagen content and solubility and sarcomere length had relatively insignificant effects on tenderness.

In addition to the correlations between MFI and muscle tenderness for both the Nguni and the Bonsmara, MFI for meat aged for 7 days also had a negative relationship with average daily gain (Bo: $r=-$ 0.44; $\mathrm{Ng}: \mathrm{r}=-0.28)$ and a positive relationship with feed conversion ratio $(\mathrm{Bo}: \mathrm{r}=0.46 ; \mathrm{Ng}: \mathrm{r}=0.51)$ measured on a carcass basis (Tables 5 and 6). The relationship between growth performance and sensory tenderness followed the same pattern, although the correlations were much lower for the Bonsmara, viz. $\mathrm{r}=$ 0.23 for ADG (carcass; $\mathrm{P}>0.05$ ) and $\mathrm{r}=0.25$ for FCR (carcass; $\mathrm{P}<0.05$ ) and non-significant for the Nguni. Calkins et al. (1987) speculated that if an increase in the concentration of catheptic enzymes occurs during rapid growth due to increased protein turnover, enhanced muscle tenderness should result due to increased stromal (connective tissue such as collagen) and contractile protein degradation. However, their study did not show any increase in enzyme or palatability traits as a result of higher growth rates, although it may be argued that higher growth rates were artificially induced by feeding regime and were not due to the intrinsic genetic ability of the animals. On the other hand, an animal genetically superior in growth performance is expected to have a higher rate of protein synthesis or a lower rate of protein breakdown, or both. These processes are controlled by various muscle enzyme systems, such as the calpain system (calpain enzymes and their inhibitor, calpastatin), which also plays a major role in meat tenderisation post mortem (Koohmaraie, 1992). Although overemphasised, the action of growth promoting agents such as $\beta$-agonists, 
is an example of the effect of this enzyme system. They are known for their enhancing effect on growth performance and detrimental effect on muscle tenderness, mainly through retardation of myofibrillar protein breakdown by the proteolytic enzyme system regulated by calpastatin (Koohmaraie, 1992). It is therefore possible that net protein gain in genetically fast-growing animals is coupled to retarded protein breakdown post mortem, resulting in less tender meat. However, although relatively high correlations were found between MFI and growth performance on the one hand and growth, muscle tenderness and MFI on the other, the direct relationship between tenderness and growth performance was low. This could probably be attributed to the fact that sensory tenderness is a combination of a number of factors other than MFI such as marbling, sarcomere length, connective tissue properties and muscle fibre traits that might have influenced the judgement of the sensory panellists.

The Nguni showed a negative relationship between FCR and white fibre percentage $(\mathrm{r}=-0.62 ; \mathrm{P}<$ $0.001)$ and a positive relationship between FCR and red fibre percentage $(\mathrm{r}=0.56 ; \mathrm{P}<0.01)$ and intermediate fibre percentage $(\mathrm{r}=0.48 ; \mathrm{P}<0.05)$. Similar relationships, although of smaller magnitude, were found for the Bonsmara, viz. $\mathrm{r}=-0.41(\mathrm{P}<0.001), \mathrm{r}=0.23$ and $\mathrm{r}=0.38(\mathrm{P}<0.01)$, respectively. ADG was also negatively correlated with red fibre percentage $(\mathrm{r}=-0.52 ; \mathrm{P}<0.01)$ and positively correlated with white fibre percentage $(\mathrm{r}=0.39 ; \mathrm{P}<0.05)$.

\section{Conclusions}

Despite definite phylogenetic differentiation between strains of Bonsmara, the only consistent differences relating to growth performance, carcass quality and meat quality were between $\mathrm{T}$ and $\mathrm{W}$. A greater IMF to SCF ratio and a greater percentage of early developing meat cuts suggest that $\mathrm{T}$ has a later carcass maturity than W. In the Nguni differences in FCR were observed the two subpopulations and trends similar to those recorded for the Bonsmara were observed for muscle tenderness. The results suggest that selection for fast growing, efficient animals may, in effect, represent selection for retarded post mortem protein breakdown. However, further investigation is needed to confirm this conclusion.

\section{References}

AOAC, 1985. Official methods of analysis. Ed. 14. Association of Official Analytical Chemists, Washington, DC.

AMSA, 1978. Guidelines for cooking and sensory evaluation of meat. American Meat Science Association, National Livestock and Meat Board, Chicago, IL.

Anon. 1994. National Beef Cattle Performance and Progeny Testing Scheme: 1980-1992 results, Compiled by D.J. Bosman. Livestock Improvement Schemes, Irene, Republic of South Africa.

Anon., 1998. South African Livestock breeding 1998. ed. J.P. Campher, C. Hunlin \& G.J. van Zyl,. South African Stud Book and Livestock Improvement Association, PO Box 270, Bloemfontein, 9300, Republic of South Africa. p. 74.

Bergman, I. \& Loxley, R., 1963. Two improved and simplified methods for the spectrophotometric determination of hydroxyproline. Analytical Chemistry, 35.

Bonsma, F. N., Bisschop, J. H. R., Curson, H. H., Van Rensburg, P., Van Rensburg, J. A., Van Wyk, H. P. P., Barnard, W. G. \& Watermeyer, F., 1951. Nguni cattle: Report on indigenous cattle in South Africa. Pamphlet no. 311 of the Department of Agriculture of the Union of South Africa.

Bonsma, J., 1980. Livestock production. A global approach. Tafelberg Publishers Ltd., Cape Town.

Bosman, D. J., 1988. Die verskillende lyne van die Bonsmara-beesras. Bonsmara J., August 1988, 7-8.

Calkins, C. R., Dutson, T. R., Smith, G. C., Carpenter, Z. L. \& Davis, G. W., 1981. Relationship of fibre type composition to marbling and tenderness of bovine muscle. J. Food Sci. 46, 708-710.

Calkins, C. R., Seideman, S. C. \& Crouse, J. D., 1987. Relationships between rate of growth, catheptic enzymes and meat palatability in young bulls. J. Anim. Sci. 64, 1448-1457.

Crosley, R. I., Heinze, P. H. \& Naudé, R. T., 1994. The relationship between beef tenderness and age classification in the South African Beef carcass classification system. Proceedings of the 40th International Conference of Meat Science and Technology The Hague, Netherlands S-III.15, 34-35.

Cross, H. R., Moen, R. \& Stanfield, M. S., 1978. Training and testing of judges for sensory analysis of meat quality. Food Technology 32, 48-54. 
Crouse, J. D., Cross, H. R. \& Seideman, S. C., 1985. Effects of sex condition, genotype, diet and carcass electrical stimulation on the collagen content and palatability of two bovine muscles. J. Anim. Sci. 60 (5), 1228-1234.

Crouse, J. D., Koohmaraie, M. \& Seideman, S. D., 1991. The relationship of muscle fibre size to tenderness of beef. Meat Sci. 30, 295-302.

Culler, R. D., Parrish, F. C., Smith, G. C. \& Cross, H. R., 1978. Relationship of myofibril fragmentation index to certain chemical, physical and sensory characteristics of bovine longissimus muscle. J. Food Sci. 43, 1177-1180.

De Bruyn, J.F., 1991.. Production and product characteristics of different cattle genotypes under feedlot conditions. D.Sc.-thesis, University of Pretoria, Pretoria, South Africa.

Devine, C. E. \& Chrystal, B. B., 1992. In: Encyclopaedia of Meat Science and Technology, ed. Y.H. Hui, p. 1708 .

Dreyer, J. H., Naudé, R. T., Henning, J. W. N. \& Rossouw, E., 1977. The influence of breed, castration and age on muscle fibre type and diameter in Friesland and Afrikaner cattle. S. Afr. J. Anim. Sci. 7, 171180.

Geesink, G. H., Koolmees, P. A., Van Laack, H. L. J. M. \& Smulders, F. J. M., 1995. Determinants of tenderisation in beef Longissimus dorsi and Triceps brachii muscles. Meat Sci.41 (1), 7-17.

Genstat, 1993. Committee of the Statistics Department. Rothamsted Experimental Station. Claredon Press, Oxford.

Gerrard, F. \& Mallion, F.J., 1977. The complete book of meat. Virtue, London, UK.

Government Gazette no.5092, 1993. Regulations regarding the classification and marking of meat: Amendment. Republic of South Africa.

Hegarty, P. V. J. \& Naudé, R. T., 1970. The accuracy of measurement of individual skeletal muscle fibres separated by a rapid technique. Laboratory Practice 19, 161-163.

Heinzé, P. H. \& Bruggeman, D., 1994. Ageing of beef: Influence of two ageing methods on sensory properties and myofibrillar proteins. Sciences Des Aliments 14, 387-399.

Hill, F., 1966. The solubility of intramuscular collagen on meat animals of various age. J. Food Sci. 31, 161164.

Instron, 1990. Series IX Automated Materials Testing System: Operating Instruction Manual. Instron Corporation Issue B November.

Jones, S. D. M., Burgess, T. D., Wilton, J. W. \& Watson, C. H., 1984. Feedlot performance, carcass composition and efficiency of muscle gain in bulls and steers of different mature size slaughtered at similar levels of fatness. Can. J. Anim. Sci. 64, 621-630.

Kempster, A. J., Cook, J. L. \& Southgate, J. R., 1982. A comparison of different breeds and crosses from the suckler herd 2. Carcass characteristics. Anim. Prod. 35, 99-111.

Kempster, A. J., Cook, J. L. \& Southgate, J. R., 1988. Evaluation of British Friesians, Canadian Holstein and Beef breed X British Friesian steers slaughtered over a commercial range of fatness from 16-month and 24-month production systems. Anim. Prod. 46, 365-378.

Kempster, A. J., Cuthbertson, A. \& Harrington, G., 1976. Fat distribution in steer carcasses of different breeds and crosses. Anim. Prod. 23, 25-34.

Kempster, A. J. \& Owen, M. G., 1981. A note on the accuracy of an ultrasonic technique for selecting cattle of different breeds for slaughter at equal fatness. Anim. Prod. 32, 113-115.

Koohmaraie, M., 1992. The role of Ca 2+-dependent proteases (calpains) in post mortem proteolyses and meat tenderness. Biochimie. 74, 239-245.

Korver, S., Tess, M. W., Johnson, T. \& Andersen, B. B., 1987. Size-scaled lean and fat growth patterns of serially slaughtered beef animals. J. Anim. Sci. 64, 1292-1301.

Lawrie, R. A., 1977. Meat: Current developments and future status. Introductory editorial. In: Meat Science I, ed. R Lawrie, p. 1. Applied Science Publishers Ltd, London.

Malaty, M. A. \& Bourne, G. H., 1953. Histochemistry of succinic dehydronase. Nature $171 \& 295$.

Marshall, D. M., 1994. Breed differences and genetic parameters for body composition traits in beef cattle. J. Anim. Sci 72, 2745-2755.

Maule, J. P., 1973. The role of the indigenous breeds for beef production in southern Africa. S. Afr. J. Anim. Sci. 3, 11-15.

Naudé, R. T., 1972. Die bepaling van spier, vet en been in karkasse van jong osse. The determination of muscle, fat and bone in the carcasses of young steers. S. Afr. J. Anim. Sci. 2, 35-39. 
Naudé, R. T. \& Boccard, R., 1973. Carcass and meat quality of Afrikaner and Jersey crossbred steers. S. Afr. J. Anim. Sci. 3, 95-100.

Naudé, R.T., 1974. Intensiewe vleisbeesproduksie uit melkrasbeeste. D.Sc.-thesis, University of Pretoria, Pretoria, South Africa.

Nel, M., 1978. Estimation of average heterozygosity and genetic distance from a small number of individuals. Genetics. 89, 583-590.

Olson, D. G. \& Parish, F. C., 1997. Relationship of myofibril fragmentation index to measures of beefsteak tenderness. J. Food Sci. 42, 506-511.

Olsson, U. \& Tornberg, E., 1992. The interrelationship between myofibril fragmentation and tenderness for beef meat. Proceedings of the 38th International Congress of Meat Science and Technology, 399-400.

Ouali, A., 1990. Meat tenderisation: possible causes and mechanisms. A Review. J. Muscle Foods 1, 129165.

Payne, W. J. A., 1964. The origin of domestic cattle in Africa. Empire J. Exp. Agric. 32 (126), 97-113.

Ronchietto, P. C., 1993. A hardy breed. African Farming. November/December, 17-18.

Savell, J. W. \& Cross, H. R., 1988. The role of fat in the palatability of beef, pork and lamb. Designing Foods 345-350.

Schoeman, S. J., 1989. Review: Recent research into the production potential of indigenous cattle with specific reference to Sanga. S. Afr. J. Anim. Sci. 19 (2), 55-61.

Scholtz, M. M., 1988. Selection possibilities of hardy beef breeds in Africa: The Nguni example. Proceedings of the 3rd World Congress on Sheep and Beef Cattle Breeds Paris, France 2, 303-304.

Seideman, S. C. \& Crouse, J. D., 1986. The effect of sex condition, genotype and diet on bovine muscle fibre characteristics. Meat Sci. 17, 55-72.

Seideman, S. C., Koohmaraie, M. \& Crouse, J. D., 1987. Factors associated with tenderness in young beef. Meat Sci. 20, 281-291.

Southgate, J. R., Cook, J. L. \& Kempster, A. J., 1982. A comparison of the progeny of British Friesian dams and different sire breeds on 16- and 24-month beef production systems 1. Live-weight gain and efficiency of food utilisation. Anim. Prod. 34, 155-166.

Stoch, C., 1993. Nguni: A hardy breed. African Farming. November/December, 17-18.

Swofford, D. L. \& Selander, R. B., 1981. Biosys-1: a Fortran program for the comprehensive analysis of electrophoretic data in population genetics and systematics. J. Heredity 72, 281-283.

Weber, R., 1973. The determination of hydroxyproline and chloride in meat and meat products: Simultaneous operation with nitrogen and phosphorus determinations. Technicon International Division S A, Technical Report 7. 